\title{
Article \\ Characterization and Biotechnological Potential of Two Native Marine Microalgae Isolated from the Tunisian Coast
}

\author{
Jamila Ben Mohamed ${ }^{1}$, Jihen Elleuch ${ }^{2}$, Marwa Drira ${ }^{1}$, Maria Ángeles Esteban ${ }^{3}{ }^{(}$, Philippe Michaud ${ }^{4, *(D)}$, \\ Slim Abdelkafi ${ }^{2}$ and Imen Fendri ${ }^{1, *} \mathbb{D}$ \\ 1 Laboratoire de Biotechnologies des Plantes Appliquées à l'Amélioration des Cultures, Faculté des Sciences, \\ Université de Sfax, Sfax 3038, Tunisia; jamila.benmohamed.etud@fss.usf.tn (J.B.M.); \\ maroua.drira.etud@fss.usf.tn (M.D.) \\ 2 Laboratoire de Génie Enzymatique et Microbiologie, Equipe de Biotechnologie des Algues, Ecole Nationale \\ d'Ingénieurs de Sfax, Université de Sfax, Sfax 3038, Tunisia; jihen.elleuch@fss.usf.tn (J.E.); \\ slim.abdelkafi@enis.tn (S.A.) \\ 3 Department of Cell Biology and Histology, University of Murcia, 30100 Murcia, Spain; aesteban@um.es \\ 4 CNRS, SIGMA Clermont, Institut Pascal, Université Clermont Auvergne, F-63000 Clermont-Ferrand, France \\ * Correspondence: philippe.michaud@uca.fr (P.M.); imen.fendri@fss.usf.tn (I.F.)
}

check for updates

Citation: Mohamed, J.B.; Elleuch,

J.; Drira, M.; Esteban, M.Á.;

Michaud, P.; Abdelkafi, S.;

Fendri, I. Characterization and

Biotechnological Potential of Two

Native Marine Microalgae Isolated from the Tunisian Coast. Appl. Sci. 2021, 11, 5295. https://doi.org/

10.3390/app11115295

Academic Editor: Raffaella Boggia

Received: 26 April 2021

Accepted: 1 June 2021

Published: 7 June 2021

Publisher's Note: MDPI stays neutral with regard to jurisdictional claims in published maps and institutional affiliations.

Copyright: (c) 2021 by the authors. Licensee MDPI, Basel, Switzerland. This article is an open access article distributed under the terms and conditions of the Creative Commons Attribution (CC BY) license (https:/ / creativecommons.org/licenses/by/ $4.0 /)$.
Featured Application: Newly isolated microalgae strains with potential applications in different fields, especially fish feeds and wastewater bioremediation.

Abstract: Microalgae are attracting considerable interest worldwide. In the present study, two native microalgae strains isolated from Tunisian cost were identified as Chlamydomonas sp. and Navicula sp. We characterized their pigment and protein contents, as well as their carbohydrate and lipid productivity. The predominant fatty acids were found to be $\alpha$-linolenic acid (C18:3n3) and palmitoleic acid (C16:1n-7) for Chlamydomonas sp. and Navicula sp. strains respectively. Microalgae methanol extracts showed important in vitro antibacterial activity against all tested gram negative bacteria. Antioxidant activities of methanol extracts were investigated by determining radical scavenging activity according to DPPH (2,2-diphenyl-1-picrylhydrazyl) and ABTS (2,2'-azinobis(3-ethylbenzothiazoline-6-sulfonic acid)) methods. MTT (3-[4,5-dimethylthiazol-2-yl]-2,5 diphenyl tetrazolium bromide) assay showed that the newly isolated microalgae were not toxic and have potential application in the fish feeds domain as a supplement in fish meal. Also, the biosorption of cadmium from aqueous solutions by microalgae living cells was evaluated. Large removal capacities were obtained with values ranging from $89.8 \%$ to $99.38 \%$. These results are very promising as a starting point for a potential application of these new isolates for in situ bioremediation of heavy metals contaminating aqueous systems.

Keywords: antibacterial activity; antioxidant activity; cadmium bioremoval capacity; Chlamydomonas sp.; Navicula sp.; unsaturated fatty acids abundance

\section{Introduction}

Microalgae comprise a vast group of both marine and freshwater habitats organisms. Based on DNA sequence data, they have been classified into ten major phyta which are Glaucophyta, Euglenophyta, Cryptophyta, Haptophyta, Dinophyta, Heterocontophyta (including diatoms), Rhodophyta, Chlorophyta, and the prokaryotic Cyanophyta (cyanobacteria) [1]. In recent years, a focus has been shifted towards these organisms due to their diverse metabolic contents. Indeed, they synthesize a large number of bioactive compounds, including pigments, sterols, polyphenols, fatty acids, proteins, vitamins, alkaloids, and sulfated polysaccharides with various chemical structures and biological activities [2,3]. These biomolecules are useful for microalgal-based feed and food, nutraceutical, pharmaceutical, and cosmetic industries through their antioxidant, antifungal, antibacterial, 
antiviral, antienzymatic, anti-cancer, or anti-inflammatory activities [4-7]. Several studies have reported the therapeutic properties of Spirulina and Nostoc species and their ability to scavenge superoxide and hydroxyl radicals and inhibit lipid peroxidation [8,9]. Besides, due to their rich nutritional properties, some Chlorophycae and diatoms genera have been widely used as dietary supplements for both humans and animals [10,11].

Nowadays, there is a focus on using microalgae in renewable energy sources as well as environmental applications. Several studies reported the conversion of microalgae biomass into biofuels $[12,13]$. Also, microalgae environmental applications are mainly represented in $\mathrm{CO}_{2}$ sequestration and wastewater treatment [14]. Recent studies have investigated microalgae capacities for the final polishing of municipal wastewater, or the direct treatment of a variety of industrial wastewaters $[14,15]$. They demonstrate that several microalgae species can uptake heavy metals with high efficiency [16]. Moreover, multiple metal-biosorption mechanisms have been reported that differ according to the species used, biomass kind, and adopted procedure [15]. These include ion exchange, chelation, complexation, and microprecipitation [16]. The goal of the present work was to isolate, identify, and characterize native microalgae strains from Tunisian coasts to study their biotechnological potentialities for future industrial-scale valorization in biotechnological fields.

\section{Materials and Methods}

\subsection{Isolation of Axenic Uniclonal Cultures}

Seawater samples were collected from the Tunisian Coast of Ksour-Essef (governorate of Mahdia) (Latitude: $35^{\circ} 23^{\prime} 32.85^{\prime \prime}$ N; Longitude: $11^{\circ} 2^{\prime} 57.1704^{\prime \prime}$ E) in February 2018. They were pre-filtered through a $60 \mu \mathrm{m}$ pore size membrane then the flow-through fractions were transferred into sterile flasks containing $\mathrm{f} / 2$-medium [17]. Inoculated cultures were grown in continuous aeration and illumination of $2000 \mathrm{lux}, 25 \pm 1^{\circ} \mathrm{C}$ until visible growth appeared in flasks. Afterwards, an aliquot of each flask was spread over a sterilized agar plate, incubated at $28{ }^{\circ} \mathrm{C}$ and continuously illuminated at a light intensity of 2000 lux until visible growth appeared in the plate. A single colony was transferred into sterile liquid $\mathrm{f} / 2$-medium aseptically. After $72 \mathrm{~h}$, cultures were examined using inverted microscopy (Motic microscope AE2000, Barcelona, Spain) at 40× magnification. The pure cultures were obtained by performing the micromanipulation method after serial dilutions [18]. Cultures were maintained in the $\mathrm{f} / 2$ medium, at $25 \pm 1{ }^{\circ} \mathrm{C}$ with continuous aeration and an illumination of 2000 lux.

\subsection{DNA Extraction, PCR Amplification, Sequencing and Phylogenetic Analysis}

The genomic DNA was extracted using phenol/chloroform extraction standard method followed by ethanol precipitation [19]. The 18S rRNA encoding gene of each isolated strain was amplified by PCR using the EukA-EukB primer pair [20] according to the procedure reported by Ben Amor et al. [21]. The PCR products obtained were purified from agarose gel using MiniElute Gel Extraction Kit (Qiagen S. A. Courtaboeuf, France) by following the instruction manual. The purified products were sequenced by Sanger sequencing using 3500 Series Genetic Analyzer by Thermo Fisher Scientific, USA. The sequences obtained were compared with the sequences available in GenBank using the BLAST server from the NCBI website (www.ncbi.nlm.nih.gov/BLAST, 26 June 2020).

\subsection{Pigments Contents}

Pigments contents were determined spectrophotometrically, in ethanol extracts, as previously detailed by Fazeli et al. [22]. Briefly, the cell density of microalgae cultures were adjusted to $5 \times 10^{9} \mathrm{cell} / \mathrm{L}$, then $2 \mathrm{~mL}$ of each culture were centrifuged at $5000 \times g$ for $10 \mathrm{~min}$. The pellet was suspended in ethanol $100 \%$ and sonicated at $65^{\circ} \mathrm{C}$ for $30 \mathrm{~min}$. After sonication, the solution was centrifuged at $5,000 \times g$ for $10 \mathrm{~min}$ then the absorbance was measured at 666, 653, and $470 \mathrm{~nm}$ using a UV/VIS spectrophotometer (Pharo 300; Merck, NJ, USA). Chlorophyll $a$, Chlorophyll $b$, and carotenoids amount were calculated according 
to the formula reported by Lichtenthaler [23]. Pigments contents were expressed in $\mathrm{mg} / \mathrm{L}$ of microalgae culture. All assays were set up in triplicates.

\subsection{Proteins Contents}

Freeze-dried samples $\left(50 \mathrm{mg}\right.$ ) were incubated at $4{ }^{\circ} \mathrm{C}$ for $12 \mathrm{~h}$ with $4 \mathrm{~mL}$ ultra-pure water then ground with a mortar and pestle. Homogenates were collected and centrifuged at $15,000 \times \mathrm{g}$ for $20 \mathrm{~min}$ at $4{ }^{\circ} \mathrm{C}$ to recover the supernatants, which were transferred to fresh centrifuge tubes and kept at $4{ }^{\circ} \mathrm{C}$. The pellets were re-extracted with $1 \mathrm{~mL}$ of $\mathrm{NaOH}(0.1 \mathrm{M})$ under the same conditions. Collected supernatants from both extractions were mixed and proteins were precipitated using cold trichloroacetic acid as detailed by Barbarino and Lourenço [24]. Precipitated proteins were suspended in $0.5 \mathrm{~mL} \mathrm{NaOH}(1 \mathrm{M})$ and quantified with the Bradford method [25]. Absorbance was recorded at $595 \mathrm{~nm}$ using a UV/VIS spectrophotometer (Pharo 300; Merck, NJ, USA). Samples were calibrated against the bovine serum albumin (Sigma) curve. Assays were made in triplicate.

\subsection{Carbohydrates Contents}

The carbohydrate content (poly- and oligo-) of the studied microalgae was assessed by the phenol sulfuric-acid colorimetric method described by Dubois et al. [26]. In brief, fresh microalgae biomass was hydrolyzed using $1 \mathrm{~mL}$ phenol $5 \%(w / v)$ and $5 \mathrm{~mL}$ concentrate sulfuric-acid. The mixture was vortexed and incubated for $10 \mathrm{~min}$ at room temperature. The absorbance was measured at $490 \mathrm{~nm}$ with a UV/VIS spectrophotometer (Pharo 300; Merck, NJ, USA). The concentration of carbohydrates was determined based on the dextrose standard curve. Three replicates were made for each assay.

\subsection{Lipids Contents and Fatty Acid Profiles}

Total lipids were prepared according to the method reported by Fendri et al. [27]. Briefly, microalgae fresh biomass $(2 \mathrm{~g})$ was homogenized with $20 \mathrm{~mL}$ of chloroform/methanol (2:1, $v / v$ ) using a tissue disrupter (IKA ULTRA-TURRAX T 25 digital; IKA-WERKE, Staufen, Germany). Non-lipid impurities were removed by washing with $\mathrm{KCl}(0.88 \%, w / v)$. Lipid weight was determined gravimetrically after evaporating the solvent under a stream of nitrogen and overnight vacuum drying. Fatty acid methyl esters (FAME) were prepared by acid-catalyzed trans-esterification of total lipids using $2 \mathrm{~mL}$ of $1 \%$ sulfuric acid $(v / v)$ in methanol, at $50{ }^{\circ} \mathrm{C}$ for $24 \mathrm{~h}$. Methyl esters were extracted twice in $5 \mathrm{~mL}$ of hexane-diethyl ether $(1: 1, v / v)$ after neutralization with $2 \mathrm{~mL}$ of $2 \% \mathrm{KHCO}_{3}$, dried under a stream of nitrogen, then dissolved in $1 \mathrm{~mL}$ of iso-hexane. The obtained FAME were analyzed through gas-liquid chromatography in an SPTM 2560 flexible fused silica capillary column (length $100 \mathrm{~mm}$, internal diameter $0.25 \mathrm{~mm}$, film thickness of $0.20 \mathrm{~mm}$ SUPELCO) in a HewlettPackard 5890 gas chromatograph. The oven temperature program was set according to the following. The initial temperature was $140{ }^{\circ} \mathrm{C}$, then it increased at a rate of $3{ }^{\circ} \mathrm{C} / \mathrm{min}$ to $230{ }^{\circ} \mathrm{C}$, followed by $2{ }^{\circ} \mathrm{C} / \mathrm{min}$ to reach $240{ }^{\circ} \mathrm{C}$ and then it was held there for $12 \mathrm{~min}$. The injector and flame ionization detector were set at $260^{\circ} \mathrm{C}$. Helium was used as the carrier gas at a column pressure of $300 \mathrm{kPa}$. Peaks were identified by comparing their retention times with appropriate FAME standards from the Sigma Chemical Company (St. Louis, MO, USA). Data for the individual components are expressed as a percentage of total content. Each extraction experiment was performed in triplicate, and each extract was independently analyzed three times.

\subsection{Determination of Phenols Contents}

Phenolic content was determined according to Folin-Ciocalteu method using a gallic acid standard (10-200 mg/mL). The absorbance was measured at $720 \mathrm{~nm}[28,29]$. Phenols contents were expressed in $\mathrm{mg} / \mathrm{mL}$ of microalgae culture using an initial cell density of $5 \times 10^{9}$ cell/L. All measurements were performed as independent triplicates. 


\subsection{Crude Extracts Preparation}

Microalgae biomass $(1 \mathrm{~g})$ was collected from 15-day-old cultures by centrifugation at $5000 \times g$ for $15 \mathrm{~min}$. Then, it was extracted twice using $15 \mathrm{~mL}$ methanol, with shaking for $20 \mathrm{~min}$ at the room temperature. The obtained extracts were dried in a rotary evaporator at $40{ }^{\circ} \mathrm{C}$ and under reduced pressure, then stored at $-20^{\circ} \mathrm{C}$ for further studies.

\subsection{DPPH Free-Radical Scavenging Assay}

The 2, 2 diphenyl-1-picrylhydrazyl (DPPH) tests were performed as previously detailed by Yan et al. [30]. An aliquot (1 mL) of algal extracts dissolved in dimethylsulfoxide (DMSO) $(100 \mu \mathrm{g} / \mathrm{mL})$ was mixed with DPPH $(0.02 \%, w / v)$ in methanol. After incubation for $1 \mathrm{~h}$ in the dark at $25^{\circ} \mathrm{C}$, the absorbance was measured at $517 \mathrm{~nm}$ using a UV/VIS spectrophotometer (Pharo 300; Merck, NJ, USA). Ascorbic acid was used as positive controls. The percentage of inhibition was calculated according to the following formula:

$$
\% \mathrm{DPPH} \text { radical scavenging }=\left[\left(A_{\text {control }}-A_{\text {test }}\right) / A_{\text {control }}\right] \times 100
$$

where $A_{\text {control }}=$ Absorbance of DPPH and $A_{\text {test }}=$ Absorbance of sample (extract $/$ ascorbic acid). All tests were carried out in triplicates.

\subsection{ABTS Radical Scavenging Assay}

ABTS tests were carried out according to the method described by Arnao et al. [31]. Briefly, $50 \mu \mathrm{L}$ of microalgae extracts dissolved in DMSO $(100 \mu \mathrm{g} / \mathrm{mL})$ were added to $950 \mu \mathrm{L}$ of cation ABTS+ and the absorbance was measured at $734 \mathrm{~nm}$ using a UV/VIS spectrophotometer (Pharo 300; Merck, NJ, USA). Ascorbic acid was used as positive control. The antioxidative activity was calculated using the formula reported by Re et al. [32].

$$
\% \text { ABTS radical scavenging }=\left[\left(A_{\text {control }}-A_{\text {test }}\right) / A_{\text {control }}\right] \times 100
$$

where $A_{\text {control }}=$ absorbance of ABTS and $A_{\text {test }}=$ absorbance of sample (extract $/$ ascorbic acid).

The ascorbic acid equivalent was computed by extrapolating the results with the standard pattern of decay using four different concentrations of ascorbic acid [33]. All analyses were performed in triplicates.

\subsection{Antioxidant Enzyme Assays}

The catalase activity was determined following the method proposed by Aebi [34]. The assay mixture consisted of $30 \mathrm{mM} \mathrm{30 \%} \mathrm{H}_{2} \mathrm{O}_{2}$ and $10 \mu \mathrm{L}$ microalgae enzyme extract. Absorbance was immediately determined at $240 \mathrm{~nm}$ using a UV/VIS spectrophotometer (Pharo 300; Merck, NJ, USA). The rate of $\mathrm{H}_{2} \mathrm{O}_{2}$ decomposition is directly proportional to the catalase activity. One unit of catalase activity is defined as the amount of enzyme required to decompose $1 \mu \mathrm{M} \mathrm{H}_{2} \mathrm{O}_{2}$. The enzyme activity was expressed as $\mathrm{U} / \mathrm{mg}$ protein.

Peroxidase activity was assayed according to established protocol [35]. Briefly, the reaction mixture consisted of $100 \mu \mathrm{L}$ guaiacol $(34 \mathrm{mM}), 100 \mu \mathrm{L} \mathrm{H}_{2} \mathrm{O}_{2}(100 \mathrm{mM})$ and $100 \mu \mathrm{L}$ of microalgae enzyme extract in phosphate buffer $(100 \mathrm{mM}, \mathrm{pH} 7)$. The rate of formation of oxidized guaiacol was followed spectrophotometrically at $470 \mathrm{~nm}$ using a UV/VIS spectrophotometer (Pharo 300; Merck, NJ, USA). Enzyme activity was calculated using the extinction coefficient of $26.6 \mathrm{mM}^{-1} \mathrm{~cm}^{-1}$. All measurements were made in triplicates.

\subsection{Antibacterial Activities}

The Gram-negative bacteria Vibrio harveyi, Vibrio Anguillarum, Photobacterium damselae, Aeromonas salmonicida, Shewanella putrefaciens (Pdp11), and Tenacibaculum mesophyllum were used as test organisms [36]. Antibacterial tests were performed in 96-well-flat-bottomed plates (Nunc, Thermo Fisher Scientific, United States), following the method of Stevens et al. [37] with slight modification. $20 \mu \mathrm{L}$ of test extracts were added to $20 \mu \mathrm{L}$ of the previously cultured bacteria (log phase) adjusted to $10^{8}$ c.f.u $/ \mathrm{mL}$. After incubation for $5 \mathrm{~h}$ 
at $25^{\circ} \mathrm{C}, 25 \mu \mathrm{L}$ of MTT $(1 \mathrm{mg} / \mathrm{mL})$ were added to each well, and incubated for $10 \mathrm{~min}$ at $25^{\circ} \mathrm{C}$ to allow the formation of formazan. Then, the plates were centrifuged at $2000 \times g$ for $10 \mathrm{~min}$. The supernatants were removed and the precipitates were dissolved in $200 \mu \mathrm{L}$ DMSO. Dissolved formazan absorbance was measured at $570 \mathrm{~nm}$. Bacteria plus sterile PBS or methanol served as negative controls. The antibacterial activities were expressed as a percentage of non-viable bacteria, calculated as the difference between absorbance of surviving bacteria compared to the absorbance of bacteria from positive control (100\%). Control and treatments were performed in triplicate.

\subsection{Cytotoxicity and Antitumor Assay}

Cytotoxicity effects of microalgae methanol extracts were evaluated against SAF-1 (ECACC ${ }^{\circ}$ 00122301) and PLHC1 (ATCC ${ }^{\circledR}$ CRL2406 ${ }^{\mathrm{TM}}$ ) cell lines, using the standard MTT method, as previously described by Espinosa Ruiz et al. [38]. The tested concentration of each microalgae extract was $0.1 \mathrm{mg} / \mathrm{mL}$. Cells incubated with medium with methanol served as a negative control. All tests were performed in five replicates.

\subsection{Cadmium Removal Capacity}

The capacity of both studied strains to remove metal was determined in batch assays, by culturing microalgal biomass $(0.02 \mathrm{~g} / \mathrm{L})$ in $\mathrm{f} / 2$ medium, containing cadmium at initial concentrations of $0.5,2.5$, and $5 \mathrm{mg} / \mathrm{L}$, under the previously mentioned conditions. After incubation for 5 days and 10 days, culture samples were collected, centrifuged, and residual cadmium concentration (in the supernatant) was determined via atomic absorption spectrophotometry (BMG LABTECH) according to the method described by Travieso et al. [39]. Then, percentages of removed cadmium were calculated. Experiments were run in triplicate. Blank controls (containing $\mathrm{f} / 2$ medium plus cadmium) and negative controls (containing $\mathrm{f} / 2$ medium and microalgae biomass) were also carried out.

\subsection{Statistical Analysis}

Statistical differences between antioxidant assay results were performed by Student's $t$-test, $n=3$, using SPSS 17.0 software (SPSS, Inc., Chicago, IL, USA). One-way ANOVA followed by Duncan multiple range tests were used to compare antibacterial activities, cytotoxicity assays, and cadmium removal capacities results. Data were considered significant when at least $p$ was $<0.05$.

\section{Results}

\subsection{Isolation and Identification of the Microalgae Strains}

Sea water samples were taken from Ksour-Essef (governorate of Mahdia) and two microalgae strains were isolated $\left(\mathrm{MA}_{\mathrm{a} 1}\right.$ and $\left.\mathrm{MA}_{\mathrm{n} 1}\right)$. Different selective nutrient media were used; $\mathrm{f} / 2$ medium provided the optimal culturing conditions. Using the EukA and EukB universal primer pairs, the amplified products of the $18 \mathrm{~S}$ rDNA genomic region, of approximately $1.8 \mathrm{~kb}$ for both isolated microalgae strains were sequenced. Based on sequence comparison against DNA sequences already available in GenBank database, the isolated strains, $\mathrm{MA}_{\mathrm{a} 1}$ and $\mathrm{MA}_{\mathrm{n} 1}$, were found to be affiliated to Chlamydomonas and Navicula genus, respectively, with more than $98 \%$ similarity. These results demonstrated that $\mathrm{MA}_{\mathrm{a} 1}$ and $\mathrm{MA}_{\mathrm{n} 1}$ belong to the Chlorophyceae and Bacillariophyceae classes, respectively.

\subsection{Biochemical Composition}

The biochemical composition of each native microalgae isolate was evaluated. The whole algal biomass compositions of newly isolated strains, $\mathrm{MA}_{\mathrm{a} 1}$ and $\mathrm{MA}_{\mathrm{n} 1}$, were summarized in Table 1. 
Table 1. Microalgae biomass composition.

\begin{tabular}{ccc}
\hline & Chlamydomonas sp. MA $_{\mathbf{a 1}}$ & Navicula sp. MA $\mathbf{n}$ 1 \\
\hline Proteins (\%) & $47.22 \pm 0.19$ & $34.16 \pm 0.05$ \\
Lipids (\%) & $25.55 \pm 0.2$ & $15.00 \pm 0.1$ \\
Carbohydrates (\%) & $27.23 \pm 0.05$ & $50.83 \pm 0.2$ \\
Chlorophyll (mg/L) & $1.5 \pm 0.3$ & $0.95 \pm 0.05$ \\
Phenols (mg/mL) & $40.5 \pm 0.15$ & $11.32 \pm 0.05$ \\
Carotenoid (mg/L) & $3.81 \pm 0.3$ & $4.72 \pm 0.15$ \\
\hline
\end{tabular}

Proteins and carbohydrates were the most abundant compounds for both studied strains, which could be of interest for several biotechnological applications. As shown in Table 1, Chlamydomonas sp. $\mathrm{MA}_{\mathrm{a} 1}$ strain accumulated a significantly higher quantity of proteins $(47.22 \%)$, lipids $(25.55 \%)$, chlorophyll $(1.5 \mathrm{mg} / \mathrm{L})$, and phenolic compounds $(40.5 \mathrm{mg} / \mathrm{mL})$ than Navicula sp. $\mathrm{MA}_{\mathrm{n} 1}$ strain. Besides, an important amount of carbohydrates $(50.83 \%)$ has been found in the algal biomass of Navicula sp. $\mathrm{MA}_{\mathrm{n} 1}$ strain.

Fatty acid profiles were determined for each isolate via fatty acid methyl esters analysis (Table 2).

Table 2. Fatty acid compositional profiles of lipid extracts from microalgae isolates.

\begin{tabular}{|c|c|c|}
\hline & \multicolumn{2}{|c|}{ Fatty Acid (Relative Percentage) } \\
\hline & Chlamydomonas Sp. $\mathrm{MA}_{\mathrm{a} 1}$ & Navicula Sp. $\mathbf{M A}_{\mathrm{n} 1}$ \\
\hline C14:0 Myristic acid & 0.69 & 4.96 \\
\hline C15:0Pentadecylicacid & 0.13 & 1.62 \\
\hline C16:0 Palmitic acid & 23.87 & 10.80 \\
\hline C18:0 Stearic acid & 4.98 & 0.45 \\
\hline C20:0 Arachidic acid & 0.27 & 0.00 \\
\hline C22:0 Behenic acid & 0.41 & 0.15 \\
\hline Total saturated (\%) & 30.35 & 17.98 \\
\hline C16:1n-7 Palmitoleic acid & 1.14 & 43.48 \\
\hline C18:1n-9 Oleic acid & 12.50 & 5.04 \\
\hline C18:1n-7 Vaccenic acid & 10.45 & 2.07 \\
\hline C20:1n-9 Gondoic acid & 1.00 & 0.14 \\
\hline C22:1n-9 Erucic acid & 0.00 & 0.08 \\
\hline C24:1n-9 Nervonic acid & 0.21 & 0.07 \\
\hline Total monounsaturated (\%) & 25.30 & 50.88 \\
\hline C18:2n-6 Linoleic acid & 5.82 & 2.91 \\
\hline C18:3n-6 $\gamma$-linoleic acid & 0.33 & 1.46 \\
\hline C20:3n-6 Dihomo- $\gamma$-linoleic acid & 0.00 & 0.56 \\
\hline C20:4n-6 Arachidonic acid & 1.41 & 5.64 \\
\hline C22:2n-6 Docosadonic acid & 0.36 & 0.14 \\
\hline C22:4n-6 Adrenic acid & 0.00 & 0.14 \\
\hline Total n-6 PUFA (\%) & 7.92 & 10.85 \\
\hline C18:3n-3 $\alpha$-linolenic acid & 30.08 & 0.00 \\
\hline C18:4n-3 Stearidonic acid & 0.00 & 0.05 \\
\hline C20:3n-3 Dihomo- $\alpha$-linolenic acid & 0.20 & 0.00 \\
\hline C20:5n-3 Eicosapentaenoic acid & 6.15 & 19.99 \\
\hline C22:6n-3 Docosahexanoic acid & 0.00 & 0.25 \\
\hline Total n-3 PUFA (\%) & 36.43 & 20.29 \\
\hline Total PUFAs (\%) & 44.35 & 31.14 \\
\hline$n-3 / n-6$ & 4.59 & 1.87 \\
\hline
\end{tabular}

Eighteen and twenty fatty acids have been identified in the present study for Chlamydomonas sp. $\mathrm{MA}_{\mathrm{a} 1}$ and Navicula sp. $\mathrm{MA}_{\mathrm{n} 1}$ isolates, respectively. Chlamydomonas sp. $\mathrm{MA}_{\mathrm{a} 1}$ strain, showed the highest portion of polyunsaturated fatty acids (PUFAs) $44.35 \%$ with 
$7.92 \%$ of n-6 PUFA and $36.43 \%$ of n-3 PUFA. Regarding $\mathrm{MA}_{\mathrm{n} 1}$ isolate, belonging to Navicula genus, MUFAs was the major portion of the total fatty acids (50.88\%) with a dominance of palmitoleic acid (C16:1n-7) (43.48\%).

\subsection{Antioxidant Activity}

Antioxidant activities of Chlamydomonas sp. $\mathrm{MA}_{\mathrm{a} 1}$ and Navicula sp. $\mathrm{Ma}_{\mathrm{n} 1}$ isolates methanol extracts were performed by two spectrophotometric methods: the 2,2-di(4-tertoctylphenyl)-1-picrylhydrazyl (DPPH) assay and the 2,2'-azinobis-(3-ethylbenzothiazoline6-sulfonic acid (ABTS) assay (Figure 1a,b).

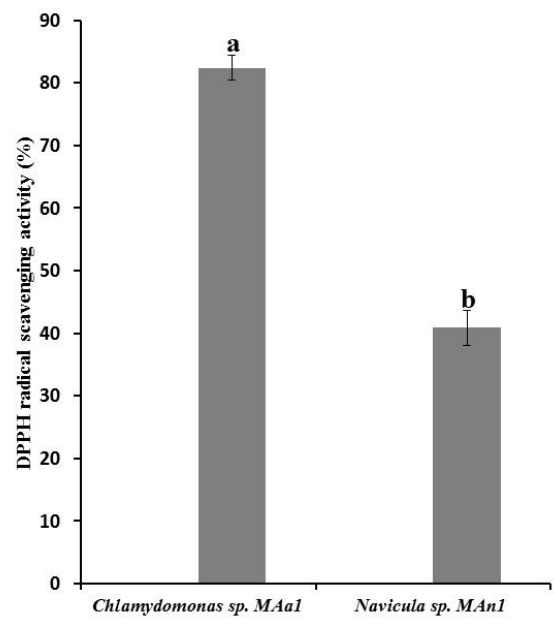

(a)

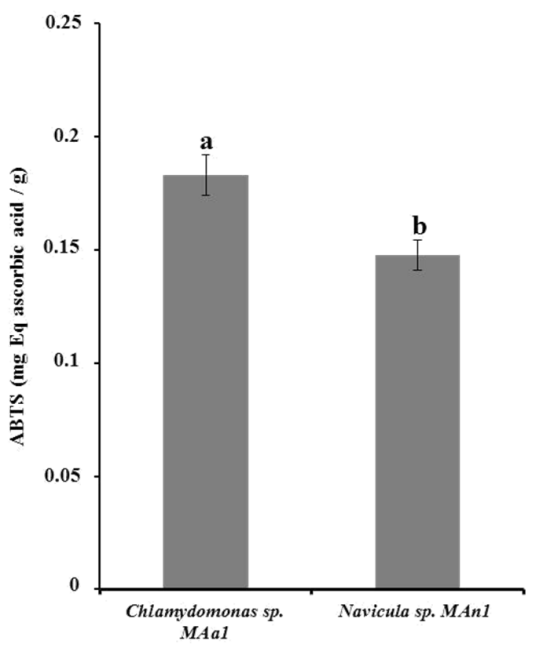

(b)

Figure 1. Non enzymatic antioxidant activities of Chlamydomonas sp. $\mathrm{MA}_{\mathrm{a} 1}$ and Navicula sp. $\mathrm{MA}_{\mathrm{n} 1}$ methanol extracts. (a) DPPH scavenging activities; (b) ABTS scavenging activities. Data show means $\pm \mathrm{SD}(n=3)$. Statistical significance was determined by a Student's $t$ test; significant difference $(p<0.05)$ is indicated by different lowercase letters.

The results obtained showed that the green microalgae isolate Chlamydomonas sp. $\mathrm{MA}_{\mathrm{a} 1}$ exhibited a higher antioxidant activity compared to Navicula sp. $\mathrm{Ma}_{\mathrm{n} 1}$ strain using both tests.

The enzymatic antioxidants from Chlamydomonas sp. $\mathrm{MA}_{\mathrm{a} 1}$ and Navicula sp. $\mathrm{Ma}_{\mathrm{n} 1}$ isolates were investigated (Figure 2).

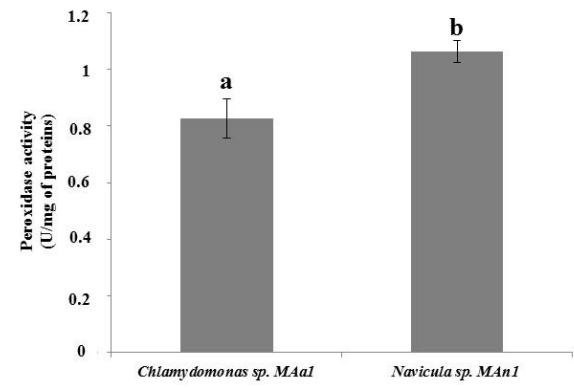

(a)

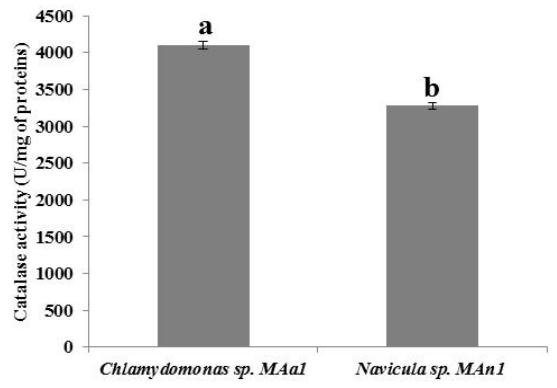

(b)

Figure 2. Enzymatic antioxidant activities of Chlamydomonas sp. $\mathrm{MA}_{\mathrm{a} 1}$ and Navicula sp. $\mathrm{MA}_{\mathrm{n} 1}$ methanol extracts. (a) Peroxidase activities; (b) catalase activities. Data show means \pm SD $(n=3)$. Statistical significance was determined by a Student's $t$ test; significant difference $(p<0.05)$ is indicated by different lowercase letters. 
The obtained peroxidase activities were $1.0625 \mathrm{U} / \mathrm{mg}$ of proteins and $0.8 \mathrm{U} / \mathrm{mg}$ of proteins for Chlamydomonas sp. $\mathrm{MA}_{\mathrm{a} 1}$ and Navicula sp. $\mathrm{MA}_{\mathrm{n} 1}$ isolates, respectively. Also, $4101.27 \mathrm{U} / \mathrm{mg}$ of protein of catalase activity was recorded for Chlamydomonas sp. $\mathrm{MA}_{\mathrm{a} 1}$ and $3281.01 \mathrm{U} / \mathrm{mg}$ of protein for Navicula sp. $\mathrm{MA}_{\mathrm{n} 1}$.

\subsection{Antibacterial Activity}

Antimicrobial activities of methanol extracts from both isolates were determined by MTT method against six Gram negative pathogenic bacteria strains for fish aquaculture: $V$. harveyi, V. anguillarum, P. damselae, A. salmonicida, S. putrefaciens (Pdp11), and T. mesophyllum (Figure 3).

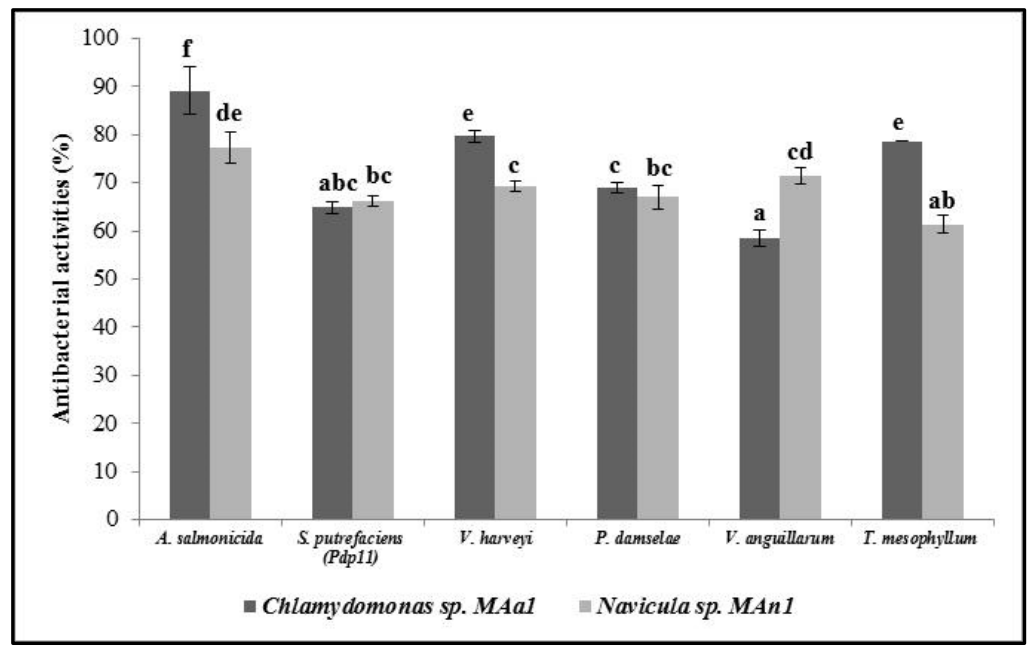

Figure 3. Antibacterial activities of Chlamydomonas sp. $\mathrm{MA}_{\mathrm{a} 1}$ and Navicula sp. $\mathrm{MA}_{\mathrm{n} 1}$ methanol extracts against $V$. harveyi, V. anguillarum, P. damselae, A. salmonicida, S. putrefaciens (Pdp11) and T. mesophyllum. Data show means $\pm \mathrm{SD}(n=3)$. Statistical significance was determined by one-way ANOVA followed by Duncan multiple range test; significant difference $(p<0.05)$ is indicated by different lowercase letters.

Methanol extracts of Chlamydomonas sp. $\mathrm{MA}_{\mathrm{a} 1}$ and Navicula sp. $\mathrm{MA}_{\mathrm{n} 1}$ exhibited interesting antibacterial activities against tested pathogenic bacteria strains. The obtained inhibition percentages were greater than $60 \%$ against all tested Gram negative pathogenic bacteria. In fact, methanol extracts of both microalgae isolates showed comparable antibacterial activities against $P$. damselae and S. putrefaciens (Pdp11) with inhibition percentages of around $65 \%$. Navicula sp. $\mathrm{MA}_{\mathrm{n} 1}$ extract was the most active against $V$. anguillarum. Interestingly, inhibition percentages greater than $80 \%$ were obtained against $V$. harveyi, $A$. salmonicida, and T. mesophyllum using Chlamydomonas sp. $\mathrm{MA}_{\mathrm{a} 1}$ extract.

\subsection{Cytotoxic Assay}

Cytotoxic effect Chlamydomonas sp. $\mathrm{MA}_{\mathrm{a} 1}$ and Navicula sp. $\mathrm{MA}_{\mathrm{n} 1}$ methanol extracts were tested against SAF-1 and PLHC-1 cells cultures using MTT colorimetric assay (Figure 4).

The obtained results showed that Navicula sp. $\mathrm{MA}_{\mathrm{n} 1}$ extract has no significant effect on cell viability of SAF-1 tested cell lines (96\%). However, it caused a slight decrease in cell viability (83\%) of PLHC-1 tumor cell lines. Regarding Chlamydomonas sp. $\mathrm{MA}_{\mathrm{a} 1}$ extract, the obtained cell viabilities were $70.4 \%$ and $91.4 \%$ using SAF-1 and PLHC-1 cell lines, respectively. 


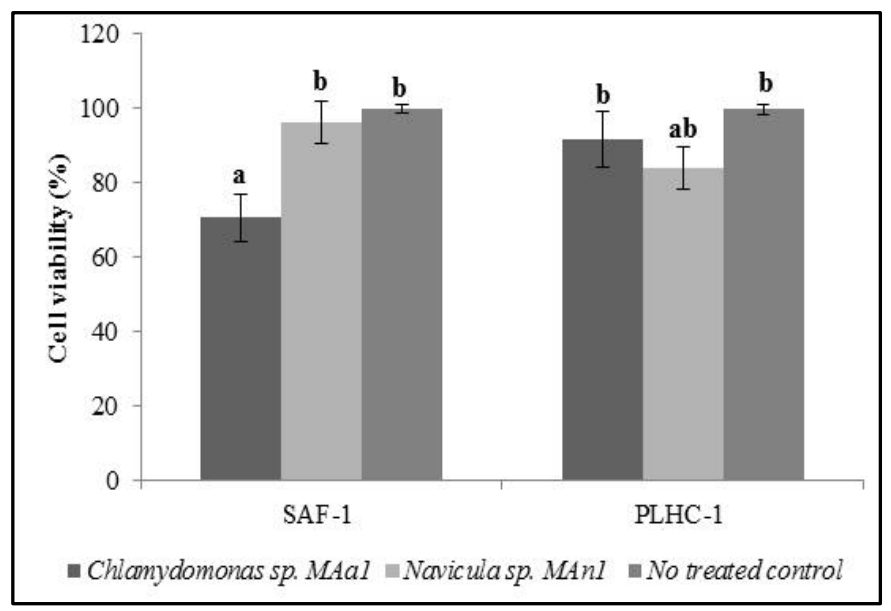

Figure 4. Cytotoxic activities of Chlamydomonas sp. $\mathrm{MA}_{\mathrm{a} 1}$ and Navicula sp. $\mathrm{MA}_{\mathrm{n} 1}$ methanol extracts against SAF-1 and PLHC-1 cell lines. Data show means \pm SD $(n=5)$. Statistical significance was determined by one-way ANOVA followed by Duncan multiple range test; significant difference $(p<0.05)$ is indicated by different lowercase letters.

\subsection{Capacity of Microalgae to Remove Heavy Metals}

The capacity of Chlamydomonas sp. $\mathrm{MA}_{\mathrm{a} 1}$ and Navicula sp. $\mathrm{MA}_{\mathrm{n} 1}$ strains to remove cadmium were tested (Figure 5).

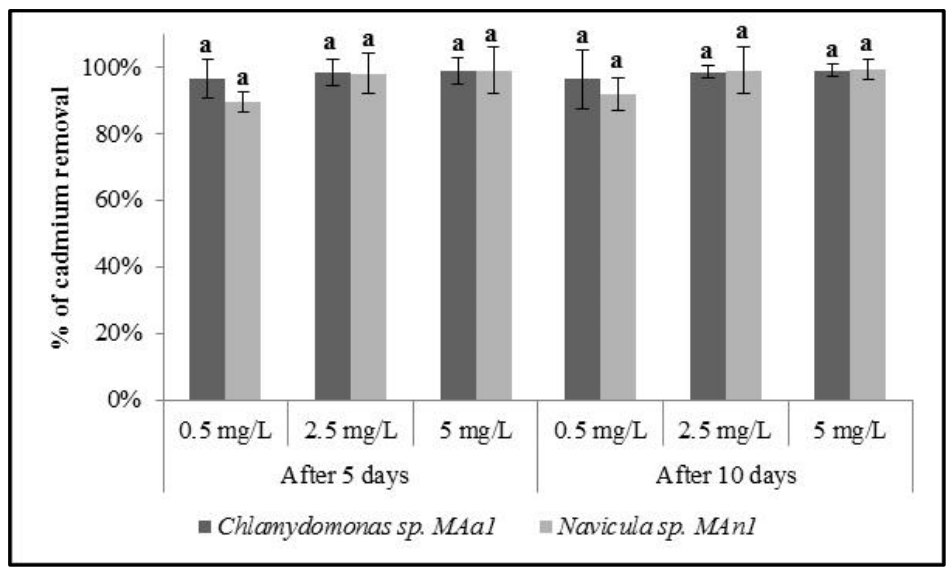

Figure 5. Capacities of Chlamydomonas sp. $\mathrm{MA}_{\mathrm{a} 1}$ and Navicula sp. $\mathrm{MA}_{\mathrm{n} 1}$ to remove cadmium from aqueous solutions. Data show means $\pm \mathrm{SD}(n=3)$. Statistical significance was determined by one-way ANOVA followed by Duncan multiple range test; no significant difference $(p<0.05)$ is indicated by the same lowercase letters.

Both tested strains exhibited high removal efficiencies of cadmium from water at all tested concentrations. In fact, the obtained percentages of removed cadmium vary between $89.8 \%$ and $99.38 \%$.

\section{Discussion}

The bio-prospecting of microalgae from local biotopes has been considered an efficient alternative to identify species of different genera that exhibit a wide of biotechnological activities $[40,41]$. In this context, two microalgae strains, $\mathrm{MA}_{\mathrm{a} 1}$ and $\mathrm{MA}_{\mathrm{n} 1}$, were isolated from local marine habitat and identified as microalgae belonging to Chlamydomonas and Navicula genera of Chlamydomonadaceae and Naviculaceae families using the nuclear $18 \mathrm{~S}$ rDNA gene as a universal DNA barcode marker [42]. Microalgae biomasses were characterized and a genus-dependent biochemical composition was observed, as previously 
reported [43]. The obtained composition of the green microalgae isolate Chlamydomonas sp. $\mathrm{MA}_{\mathrm{a} 1}$ was in agreement with that reported by Behl et al. [44], with a remarkable abundance of proteins of about $47.22 \%$, while Navicula sp. $\mathrm{MA}_{\mathrm{n} 1}$ strain biomass was richer in organic compounds especially carbohydrates (50.83\%) than previously studied Navicula isolates $[45,46]$. The growth pattern and biochemical composition of microalga cells are closely related to biotic and abiotic culture parameters such as cultivation conditions and nutrient media composition and concentrations [44].

Both newly isolated strains exhibited moderate lipid contents. However, they were found to exhibit important proportions of mono-unsaturated and polyunsaturated fatty acids; $69.65 \%$ and $82.02 \%$ for Chlamydomonas sp. $\mathrm{MA}_{\mathrm{a} 1}$ and Navicula sp. $\mathrm{MA}_{\mathrm{n} 1}$, respectively. Fatty acid profiles have been considered as chemotaxonomical characteristics, since a comparatively higher homology of fatty acid profiles is always found within the strains with closer phylogenic relationships [47]. Chlamydomonas sp. $\mathrm{MA}_{\mathrm{a} 1}$ strain is particularly rich in monounsaturated especially oleic acid (C18:1n-9), vaccenic acid (C18:1n-7), and polyunsaturated $\alpha$-linolenic acid (C18:3n-3) accounting for approximately $12.5 \%, 10.5 \%$, and $30.08 \%$ of the total Chlamydomonas sp. $\mathrm{MA}_{\mathrm{a} 1}$ oil, respectively. The main abundant fatty acid in Navicula sp. $\mathrm{MA}_{\mathrm{n} 1}$ isolate is palmitoleic acid (C16:1n-7) representing $43.48 \%$ of the total fatty acids. The obtained results agree with multiple previously-published reports showing that almost all diatoms contained high proportions of (C16: 0) and (C16: 1n-7) fatty acids [48]. Unsaturated fatty acid production should be of great importance in different fields such as special human or animal dietary, nutraceuticals, and/or cosmeceuticals given the functional properties of PUFAs and their health benefits [44]. In fact, PUFAs, especially n-3 PUFAs, have many potential applications including disease prevention and treatment [49].

Under oxidizing conditions, microalgae cells produce various antioxidants [50]. There are several reports on the evaluation of the antioxidant activity of many genera belonging to Cyanobacteria [51,52], Chlorophycae [53-55] and some diatoms [56]. The antioxidant and antibacterial properties investigation of newly isolated strains showed high potential of in vitro activities. In fact, methanolic extracts from both studied strains exhibited interesting antibacterial activities against six Gram negative pathogenic bacteria strains. These results seem to be in perfect agreement with the data of biochemical compositions since a significant relationship between total antioxidant activity and total phenolic compounds has been reported $[57,58]$. It is worth noting that microalgae methanolic extracts seem to be particularly rich in flavonoids, and that terpenes and carbohydrate were present in moderate amount and alkaloids were also found at trace levels in $[59,60]$. Previously, a correlation between metabolites like flavonoids, terpenes and carbohydrates presence and antibacterial activities was established [59,60].

Additionally, important antimicrobial activities of both microalgae extracts were obtained against tested Gram- bacteria pathogen for vertebrates and invertebrate marine animals, especially fish, bivalves, and crustaceans. Those activities could be due to the presence of bioactive compounds that may include isoprenoids, polyketides, polyunsaturated fatty acids, and alkaloids which may affect the growth and metabolism of bacteria [61,62]. It has been reported that antibacterial activities of microalgae extracts, against both Gram+ and Gram- bacteria, were attributed to eicosapentaenoic acid and palmitoleic acid, particularly produced by diatoms $[63,64]$. Interestingly, no antibacterial activities of Chlamydomonas or Navicula species against aquatic animal pathogen have been previously reported. However, antibacterial activities were described for Chlamydomonas reinhardtii and Navicula sp. against human pathogenic bacteria such us Staphylococcus aureus, Escherichia coli, Salmonella typhi, and Bacillus sp. [65,66]. Darah and Lim [67] reported the mechanisms of action involved in the bacterial killing process. Among them are the interactions of the antimicrobial compounds with the cell membrane and intracellular accumulation through the cell wall and membrane permeability [68].

To ensure algae biomass safety for potential feed supplement applications, the toxicity of microalgae extracts was studied against fish cell lines. Hepatocytes, such as PLHC1 cells, 
are good models for studying toxicity since the liver is the primary site for drug metabolism and biotransformation [69]. According to Abdillahi et al. [70], treated concentrations of Chlamydomonas sp. $\mathrm{MA}_{\mathrm{a} 1}$ and Navicula sp. $\mathrm{MA}_{\mathrm{n} 1}$ methanol extracts are considered nontoxic since the cell viability is greater than $70 \%$. In recent years, many studies have reported the in vivo immunostimulant effect of different microalgae such as Nannochloropsis gaditana, Tetraselmis chuii, and Phaeodactylum tricornutum on fish production [71,72].

Microalgae have been gaining attention in the treatment of wastewater, especially those contaminated by heavy metal. Interestingly, the newly isolated strains showed large cadmium removal capacities, with values ranging from $89.8 \%$ to $99.38 \%$. Previously, rapid cadmium bioremoval by diatom cells has been observed in several other studies using cadmium concentration lower than that tested in the present study. In fact, Navicula incerta showed linear removal of cadmium using initial ion metal concentrations of $5 \mathrm{mg} / \mathrm{L}$ [73]. Cherifi et al. [74] also reported a cadmium removal capacity of Navicula subminuscula in aqueous solution containing $8 \mathrm{mg} / \mathrm{L}$ cadmium.

Chlamydomonas genus has a great potential in metal remediation [75]. Mera et al. [76] reported that Chlamydomonas moewusii remove up to $8 \mathrm{mg} / \mathrm{L}$ of cadmium. Also, Chlamydomonas reinhardtii remove up to $42.6 \mathrm{mg} / \mathrm{L} 67.4 \mathrm{mg} / \mathrm{L}$ of cadmium using fresh cells and lyophilized biomass, respectively $[77,78]$. Several other microalgae have shown an important ability to remove cadmium ions, especially Spirulina platensis and Chlorella vulgaris [79-81]. It is worth noting that the initial concentration of metal ions, contact time, $\mathrm{pH}$, temperature, biosorbent concentration, and agitation rate are key factors affecting biosorption efficiency $[82,83]$.

\section{Conclusions}

Two microalgae strains $\mathrm{MA}_{\mathrm{a} 1}$ and $\mathrm{MA}_{\mathrm{n} 1}$ were isolated from seawater of Tunisia costs and molecularly identified as Chlamydomonas sp. and Navicula sp., respectively. Both strains were initially characterized and exhibited significant heterogeneity in key parameters, such as carbohydrate productivity, lipid productivity, and fatty acids composition. Investigation of their biological activities showed that the newly isolated strains exhibited interesting antioxidant and antibacterial activities, particularly Chlamydomonas sp. $\mathrm{MA}_{\mathrm{a} 1}$. Chlamydomonas sp. $\mathrm{MA}_{\mathrm{a} 1}$, and Navicula sp. $\mathrm{MA}_{\mathrm{n} 1}$ biomass safety was verified against fish cell lines which support their potential application in the fish feeds domain. Furthermore, both isolated strains were capable of removing cadmium from aqueous solution, opening the horizon towards their application in the wastewater treatment domain.

Author Contributions: Conceptualization, J.E., P.M., S.A., I.F.: methodology, J.B.M., I.F., M.Á.E.; Formal analysis, J.B.M., J.E., M.D., Supervision, I.F.; Investigation, J.B.M., M.D.; I.F., J.E. Writing original draft, J.B.M., I.F.; writing review and editing, J.B.M., S.A., I.F., M.Á.E., J.E., P.M. All authors have read and agreed to the published version of the manuscript.

Funding: This research was funded by the TUNISIAN MINISTRY OF HIGHER EDUCATION AND SCIENTIFIC RESEARCH. The funders had no role in study design, data collection and analysis, decision to publish and preparation of the manuscript.

Institutional Review Board Statement: Not applicable.

Informed Consent Statement: Not applicable.

Acknowledgments: This work was supported by grants from the Tunisian Ministry of Higher Education and Scientific Research.

Conflicts of Interest: The authors declare no conflict of interest. 


\section{References}

1. Groendahl, S.; Kahlert, M.; Fink, P. The best of both worlds: A combined approach for analysing microalgal diversity via metabar coding and morphology-based methods. PLoS ONE 2017, 12, e0172808. [CrossRef] [PubMed]

2. Dammak, M.; Haase, S.M.; Miladi, R.; Ben Amor, F.; Barkallah, M.; Gosset, D.; Pichon, C.; Huchzermeyer, B.; Fendri, I.; Denis, M.; et al. Enhanced lipid and biomass production by a newly isolated and identified marine microalga. Lipids Health Dis. 2016, 15, 209. [CrossRef]

3. Nehmé, R.; Atieh, C.; Fayad, S.; Claude, B.; Chartier, A.; Tannoury, M.; Elleuch, F.; Abdelkafi, S.; Pichon, C.; Morin, P. Microalgae amino acid extraction and analysis at nanomolar level using electroporation and capillary electrophoresis with laser-induced fluorescence detection. J. Sep. Sci. 2016, 40, 558-566. [CrossRef] [PubMed]

4. Ben Hlima, H.; Bohli, T.; Kraiem, M.; Ouederni, A.; Mellouli, L.; Michaud, P.; Abdelkafi, S.; Smaoui, S. Combined effect of Spirulina platensis and Punica granatum peel extacts: Phytochemical content and antiphytophatogenic activity. Appl. Sci. 2019, 9, 5475. [CrossRef]

5. Ben Hlima, H.; Dammak, M.; Karkouch, N.; Hentati, F.; Laroche, C.; Michaud, P.; Fendri, I.; Abdelkafi, S. Optimal cultivation towards enhanced biomass and floridean starch production by Porphyridium marinum. Int. J. Biol. Macromol. 2019, 129, 152-161. [CrossRef]

6. Elleuch, F.; Baril, P.; Barkallah, M.; Perche, F.; Abdelkafi, S.; Fendri, I.; Pichon, C. Deciphering the biological activities of Dunaliella sp. aqueous extract from stressed conditions on breast cancer: From in vitro to in vivo investigations. Int. J. Mol. Sci. 2020, 21, 1719. [CrossRef] [PubMed]

7. Elleuch, J.; Hadj Kacem, F.; Amor, F.B.; Hadrich, B.; Michaud, P.; Fendri, I.; Abdelkafi, S. Extracellular neutral protease from Arthrospira platensis: Production, optimization and partial characterization. Int. J. Biol. Macromol. 2021, 167, 1491-1498. [CrossRef]

8. Yasin, D.; Zafaryab, M.; Ansari, S.; Ahmad, N.; Khana, N.F.; Zaki, A.; Rizvi, M.M.A.; Fatma, T. Evaluation of antioxidant and anti-proliferative efficacy of Nostoc muscorum NCCU-442. Biocatal. Agric. Biotechnol. 2019, 17, 284-293. [CrossRef]

9. Santos, D.S.; Lauria, P.S.S.; Evangelista, A.F.; Azeredo, F.J.; Costa, J.A.V.; Soares, M.B.P.; Druzian, J.I.; Villarreal, C.F. Beyond inflammation: Centrally mediated antinociceptive properties of Spirulina platensis LEB-18 biomass via the opioid system. J. Funct. Foods 2020, 72, 104083. [CrossRef]

10. Barkallah, M.; Ben Slima, A.; Elleuch, F.; Fendri, I.; Pichon, C.; Abdelkafi, S.; Baril, P. Protective role of Spirulina platensis against bifenthrin-induced reprotoxicity in adult male mice by reversing expression of altered histological, biochemical, and molecular markers including microRNAs. Biomolecules 2020, 10, 7539. [CrossRef] [PubMed]

11. Torres-Tiji, Y.; Fields, F.J.; Mayfield, S.P. Microalgae as a future food source. Biotechnol. Adv. 2020, 41, 107536. [CrossRef]

12. Bošnjaković, M.; Sinaga, N. The perspective of large-scale production of algae biodiesel. Appl. Sci. 2020, 10, 8181. [CrossRef]

13. Fattah, I.M.R.; Noraini, M.Y.; Mofijur, M.; Silitonga, A.S.; Badruddin, I.A.; Khan, T.M.Y.; Ong, H.C.; Mahlia, T.M.I. Lipid extraction maximization and enzymatic synthesis of biodiesel from microalgae. App. Sci. 2020, 10, 6103. [CrossRef]

14. Gupta, S.; Pawar, S.B.; Pandey, R.A. Current practices and challenges in using microalgae for treatment of nutrient rich wastewater from agro-based industries. Sci. Total Environ. 2019, 687, 1107-1126. [CrossRef] [PubMed]

15. Benedetti, M.; Vecchi, V.; Barera, S.; Dall'Osto, L. Biomass from microalgae: The potential of domestication towards sustainable biofactories. Microb. Cell Factories 2018, 17, 173. [CrossRef]

16. Elleuch, J.; Barkallah, M.; Smith, K.F.; Ben Neila, I.; Fendri, I.; Abdelkafi, S. PCR assay for the simultaneous identification and enumeration of multiple Karenia species. Environ. Sci. Poll. Res. 2020, 27, 36889-36899. [CrossRef]

17. Ben Amor, F.; Elleuch, F.; Ben Hlima, H.; Garnier, M.; Saint-Jean, B.; Barkallah, M.; Pichon, C.; Abdelkafi, S.; Fendri, I. Proteomic analysis of the chlorophyta Dunaliella new strain AL-1 revealed global changes of metabolism during high carotenoid production. Mar. Drugs 2017, 15, 293. [CrossRef] [PubMed]

18. Dammak, M.; Hadrich, B.; Barkallah, M.; Hentati, F.; Ben Hlima, H.; Pichon, C.; Denis, M.; Fendri, I.; Michaud, P.; Abdelkafi, S. Modelling Tetraselmis sp. growth-kinetics and optimizing bioactive-compound production through environmental conditions. Bioresour. Technol. 2018, 249, 510-518. [CrossRef]

19. Wittkopp, T.M. Isolation of genomic DNA from Chlamydomonas reinhardtii. Bio-Protocol 2018, e2838. [CrossRef]

20. Chtourou, H.; Dahmen, I.; Hassairi, I.; Abdelkafi, S.; Sayadi, S.; Dhouib, A. Dunaliella sp. a wild algal strain isolated from the Sfax-Tunisia solar evaporating salt-ponds, a high potential for biofuel production purposes. J. Biobased Mater. Bioenergy 2014, 8 , 27-34. [CrossRef]

21. Ben Amor, F.; Barkallah, M.; Elleuch, F.; Karkouch, N.; Dammak, M.; Baréa, B.; Villeneuve, P.; Abdelkafi, S.; Fendri, I. Cyanobacteria as source of marine bioactive compounds: Molecular specific detection based on $\Delta 9$ desaturase gene. Int. J. Biol. Macromol. 2017, 105, 1440-1445. [CrossRef]

22. Fazeli, M.R.; Tofighi, H.; Samadi, N.; Jamalifar, H.; Fazeli, A. Carotenoids ccumulation by Dunaliella tertiolecta (Lake Urmia isolate) and Dunaliella salina (CCAP 19/18 \& WT) under stress conditions. DARU J. Pharm. Sci. 2006, 14, 146-150.

23. Lichtenthaler, H.K. Chlorophylls and carotenoids: Pigments of photosynthetic biomembranes. Methods Enzymol. 1987, 148, 350-382.

24. Barbarino, E.; Lourenço, S.O. An evaluation of methods for extraction and quantification of protein from marine macro-and microalgae. J. Appl. Phycol. 2005, 17, 447-460. [CrossRef]

25. Elleuch, J.; Jaoua, S.; Ginibre, C.; Chandre, F.; Tounsi, S.; Zghal, R.Z. Toxin stability improvement and toxicity increase against dipteran and lepidopteran larvae of Bacillus thuringiensis crystal protein Cry2Aa Pest. Manag. Sci. 2016, 72, 2240-2246. [CrossRef] 
26. Dubois, M.; Gilles, K.A.; Hamilton, J.K.; Rebers, P.A.; Smith, F. Colorimetric method for determination of sugars and related substances. Anal. Chem. 1956, 28, 350-356. [CrossRef]

27. Fendri, I.; Chaari, A.; Dhouib, A.; Jlassi, B.; Abousalham, A.; Carrière, F.; Sayadi, S.; Abdelkafi, S. Isolation, identification and characterization of a new lipolytic Pseudomonas sp., strain AHD-1, from Tunisian soil. Environ. Technol. 2010, 31, 87-95. [CrossRef] [PubMed]

28. Singleton, V.L.; Orthofer, R.; Lamuela-Raventos, R.M. Analysis of total phenols and other oxidation substrates and antioxidant by means of Folin-Ciocalteu reagent. Methods Enzymol. 1999, 299, 152-178. [CrossRef]

29. Abdelkafi, S.; Labat, M.; Ben Ali Gam, Z.; Lorquin, J.; Sayadi, S. Optimized conditions for the synthesis of vanillic acid under hypersaline conditions by Halomonas elongata DSM 2581 ${ }^{\mathrm{T}}$ resting cells. World J. Microbiol. Biotechnol. 2018, 24, 675-680. [CrossRef]

30. Yan, X.; Nagata, T.; Fan, X. Antioxidative activities in some common seaweeds. Plant Foods Hum. Nutr. 1998, 52, 253-262. [CrossRef]

31. Arnao, M.B.; Cano, A.; Acosta, M. Methods to measure the antioxidant activity in plant material. A comparative discussion. Free Radic. Res. 1999, 31, 89-96. [CrossRef] [PubMed]

32. Re, R.; Pellegrini, N.; Proteggente, A.; Pannala, A.; Yang, M.; Rice-Evans, C. Antioxidant activity applying an improved ABTS radical cation decolorization assay. Free Radic. Biol. Med. 1999, 26, 1231-1237. [CrossRef]

33. Scott, S.L.; Chen, W.J.; Bakac, A.; Espenson, J.H. Spectroscopic parameters, electrode potentials, acid ionisation constants and electron exchange rates of the 2,2'-azinobis(3-ethylbenzothiazoline-6-sulfonate) radicals and ions. J. Phys. Chem. 1993, 97, 6710-6714. [CrossRef]

34. Aebi, H. Catalase in vitro. Methods. Enzymol. 1984, 105, 121-126. [CrossRef]

35. Singh, S.; Verma, A.; Dubey, V.K. Effectivity of anti-oxidative enzymatic system on diminishing the oxidative stress induced by aluminium in chickpea (Cicer arietinum L.) seedlings. Braz. J. Plant Physiol. 2012, 24, 47-54. [CrossRef]

36. Ben Hsouna, A.; Ben Halima, N.; Abdelkafi, S.; Hamdi, N. Essential oil from Artemisia phaeolepis: Chemical composition and antimicrobial activities. J. Oleo Sci. 2013, 62, 973-980. [CrossRef] [PubMed]

37. Stevens, M.G.; Kehrli, M.E., Jr.; Canning, P.C. A colorimetric assay for quantitating bovine neutrophil bactericidal activity. Vet. Immunol. Immunopathol. 1991, 28, 45-56. [CrossRef]

38. Espinosa Ruiz, C.; Manuguerra, S.; Cuesta, A.; Santulli, A.; Messina, C.M. Oxidative stress, induced by sub-lethal doses of BDE 209, promotes energy management and cell cycle modulation in the marine fish cell line SAF-1. Int. J. Environ. Res. Public Health 2019, 16, 474. [CrossRef]

39. Travieso, L.; Canizares, R.O.; Borja, R.; Benitez, F.; Dominguez, A.R.; Valiente, V. Heavy metal removal by microalgae. Bull. Environ. Contam. Toxicol. 1999, 62, 144-151. [CrossRef]

40. Pradhan, J.; Das, S.; Das, B.K. Antibacterial activity of freshwater microalgae: A review. Afr. J. Pharm. Pharmacol. 2014, 8, 809-818. [CrossRef]

41. Kroumov, A.D.; Scheufele, F.B.; Trigueros, D.E.G.; Modenes, A.N.; Zaharieva, M.; Najdenski, H. Algal Green Chemistry; Elsevier: Amsterdam, The Netherlands, 2017; pp. 201-241.

42. Beszteri, B.; Acs, E.; Makk, J.; Kovács, G.; Márialigeti, K.; Kiss, K.T. Phylogeny of six naviculoid diatoms based on $18 \mathrm{~S}$ rDNA sequences. Int. J. Syst. Evol. Microbiol. 2001, 51, 1581-1586. [CrossRef] [PubMed]

43. Olsson, J.; Toth, G.B.; Albers, E. Biochemical composition of red, green and brown seaweeds on the Swedish west coast. J. Appl. Phycol. 2020, 32, 3305-3317. [CrossRef]

44. Behl, K.; SeshaCharan, P.; Joshi, M.; Sharma, M.; Mathur, A.; Kareya, M.S.; Jutur, P.P.; Bhatnagar, A.; Nigam, S. Multifaceted applications of isolated microalgae Chlamydomonas sp. TRC-1 in wastewater remediation, lipid production and bioelectricity generation. Bioresour. Technol. 2020, 304, 122993. [CrossRef]

45. Fimbres-Olivarria, D.; López-Elias, J.A.; Martínez-Córdova, L.R.; Carvajal-Millan, E.; Enriquez-Ocana, F.; Valdéz-Holguin, E.; Miranda-Baeza, A. Growth and biochemical composition of Navicula sp. cultivated at two light intensities and three wavelengths. Isr. J. Aquac. 2015, 67, 1155. [CrossRef]

46. Brown, M.; Jeffrey, S.; Volkman, J.; Dunstan, G. Nutritional properties of microalgae for mariculture. Aquaculture 1997, 151, 315-331. [CrossRef]

47. Yang, H.-L.; Lu, C.-K.; Chen, S.-F.; Chen, Y.-M.; Chen, Y.-M. Isolation and characterization of taiwanese heterotrophic microalgae: Screening of strains for docosahexaenoic acid (DHA) production. Mar. Biotechnol. 2010, 12, 173-185. [CrossRef] [PubMed]

48. Liang, Y.; Mai, K.; Sun, S. Total lipid and fatty acid composition of eight strains of marine diatoms. Chin. J. Oceanol. Limnol. 2000, 18, 345-349. [CrossRef]

49. Balic, A.; Vlasic, D.; Zuzul, K.; Marinovic, B.; Mokos, Z.B. Omega-3 versus Omega-6 polyunsaturated fatty acids in the prevention and treatment of inflammatory skin diseases. Int. J. Mol. Sci. 2020, 21, 741. [CrossRef]

50. Matsukawa, A.; Hogaboam, C.M.; Lukacs, N.W.; Lincoln, P.M.; Strieter, R.M.; Kunkel, S.L. Endogenous MCP-1 influences systemic cytokine balance in a murine model of acute septic peritonitis. Exp. Mol. Pathol. 2000, 68, 77-84. [CrossRef]

51. Jaime, L.; Mendiola, J.A.; Herrero, M.; Soler-Rivas, C.; Santoyo, S.; Senorans, F.; Cifuentes, A. Ibanez, E. Separation and characterization of antioxidants from Spirulina platensis microalga combining pressurized liquid extraction, TLC, and HPLC-DAD. J. Sep. Sci. 2005, 28, 2111-2119. [CrossRef]

52. Li, H.-B.; Cheng, K.-W.; Wong, C.-C.; Fan, K.-W.; Chen, F.; Jiang, Y. Evaluation of antioxidant capacity and total phenolic content of different fractions of selected microalgae. Food. Chem. 2007, 102, 771-776. [CrossRef] 
53. Wu, L.; Ho, J.A.; Shieh, M.-C.; Lu, I.-W. Antioxidant and antiproliferative activities of Spirulina and Chlorella water extracts. J. Agric. Food Chem. 2005, 53, 4207-4212. [CrossRef] [PubMed]

54. Herrero, M.; Jaime, L.; Martín-Álvarez, P.J.; Cifuentes, A.; Ibañez, E. Optimization of the extraction of antioxidants from Dunaliella salina microalga by pressurized liquids. J. Agric. Food Chem. 2006, 54, 5597-5603. [CrossRef]

55. Rao, A.R.; Sarada, R.; Baskaran, V.; Ravishankar, G.A. Antioxidant activity of Botryococcus braunii extract elucidated in vitro models. J. Agric. Food. Chem. 2006, 54, 4593-4599. [CrossRef] [PubMed]

56. Karthikeyan, P.; Manimaran, K.; Sampathkumar, P.; Jaikumar, M.; Robin, R.S.; Saravanakumar, C.; Sureshkuma, C. In vitro antioxidant activity of marine diatoms. OSR J. Environ. Sci. Toxicol. Food. Technol. 2013, 5, 32-37. [CrossRef]

57. Jimenez-Escrig, A.; Jimenez-Jimenez, I.; Pulido, R.; Saura-Calixto, F. Antioxidant activity of fresh and processed edible seaweeds. J. Sci. Food Agric. 2001, 81, 530-534. [CrossRef]

58. Safafar, H.; van Wagenen, J.; Moller, P.; Jacobsen, C. Carotenoids, phenoliccompounds and tocopherols contribute to the antioxidative properties of some microalgae species grown on industrial wastewater. Mar. Drugs 2015, 13, 7339-7356. [CrossRef]

59. Dineshkumar, R.; Narendran, R.; Jayasingam, P.; Sampathkumar, P. Cultivation and chemical composition of microalgae Chlorella vulgaris and its antibacterial activity against human pathogens. J. Aquac. Mar. Biol. 2017, 5, 00119. [CrossRef]

60. Little, S.M.; Senhorinho, G.N.A.; Saleh, M.; Basiliko, N.; Scott, J.A. Antibacterial compounds in green microalgae from extremeenvironments: A review. Algae 2021, 36, 61-72. [CrossRef]

61. Costa, M.; Costa-Rodrigues, J.; Fernandes, M.H.; Barros, P.; Vasconcelos, V.; Martins, R. Marine cyanobacteria compounds with anticancer properties: A review on the implication of apoptosis. Mar. Drugs 2012, 10, 2181-2207. [CrossRef]

62. Gupta, V.; Ratha, S.K.; Sood, A.; Chaudhary, V.; Prasanna, R. New insights into the biodiversity and applications of cyanobacteria (blue-green algae): Prospects and challenges. Algal. Res. 2013, 2, 79-97. [CrossRef]

63. Ward, O.P.; Singh, A. Omega-3/6 fatty acids: Alternative sources of production. Process. Biochem. 2005, 40, 3627-3652. [CrossRef]

64. Smith, V.J.; Desbois, A.P.; Dyrynda, E.A. Conventional and unconventional antimicrobials from fish, marine invertebrates and micro-algae. Mar. Drugs 2010, 8, 1213-1262. [CrossRef] [PubMed]

65. Okunowo, W.O.; Oyedeji, A.O.; Ilesanmi, J.A.; Afolabi, L.O.; Umunnakwe, I.E. Antimicrobial, antioxidant potential and chemical composition of the methanolic extracts of Spirogyra setiformis and Navicula species. J. Sci. Res. Dev. 2018, 2, 15-20.

66. Amaro, H.M.; Guedes, A.C.; Malcata, F.X. Antimicrobial activities of microalgae: An invited review. In Science against Microbial pathogens: Communicating Current Research and Technological Advances; Méndez-Vilas, A., Ed.; Formatex: Badajoz, Spain, 2011; pp. 1272-1280.

67. Darah, I.; Lim, S.H.; Ninthianantham, K. Effects of methanolic extract of Wedelia chinensis Osbeck (Asteraceae) leaves against pathogenic bacteria with emphasize on Bacillus cereus. Indian J. Pharm. Sci. 2013, 75, 533-539. [CrossRef] [PubMed]

68. Abu-Shanab, B.; Adwan, G.; Abu-Safiya, D.; Adwan, K.; Abu-Shanab, M. Antibacterial activity of Rhus coriaria. L. extracts growing in Palestine. J. Islamic Univ. Gaza 2005, 13, 147-153.

69. Lauritano, C.; Andersen, J.H.; Hansen, E.; Albrigtsen, M.; Escalera, L.; Esposito, F.; Helland, K.; Hanssen, K.; Romano, G.; Ianora, A. Bioactivity screening of microalgae for antioxidant, anti-inflammatory, anticancer, anti-diabetes, and antibacterial activities. Front. Mar. Sci. 2016, 3, 68. [CrossRef]

70. Abdillahi, H.S.; Verschaeve, L.; Finnie, J.F.; Van Staden, J. Mutagenicity, antimutagenicity and cytotoxicity evaluation of south African Podocarpus species. J. Ethnopharmacol. 2012, 139, 728-738. [CrossRef]

71. Cerezuela, R.; Guardiola, F.A.; Meseguer, J.; Esteban, M.A. Enrichment of gilthead seabream (Sparusaurata L. ) diet with microalgae: Effects on the immune system. Fish. Physiol. Biochem. 2012, 38, 1729-1739. [CrossRef] [PubMed]

72. Yadav, G.; Meena, D.K.; Sahoo, A.K.; Das, B.K.; Sen, R. Effective valorization of microalgal biomass for the production of nutritional fish-feed supplements. J. Clean. Prod. 2020, 243, 118697. [CrossRef]

73. Al-Quraishi, D.O.; Al-Mayaly, I.K. Biosorption of Ccadmium, lead and nickel in their aqueous solution by Nitzschia palea and Navicula incerta. J. Eng. Appl. Sci. 2019, 14, 9114-9120.

74. Cherifi, O.; Sbihi, K.; Bertrand, M.; Cherifi, K. The removal of metals (Cd, $\mathrm{Cu}$ and $\mathrm{Zn}$ ) from the Tensift river using the diatom Navicula subminuscula Manguin: A laboratory study. Int. J. Adv. Res. Biol. Sci. 2016, 3, 177-187. [CrossRef]

75. Kumar, K.S.; Dahms, H.U.; Won, E.J.; Lee, J.S.; Shin, K.H. Microalgae-A promising tool for heavy metal remediation. Ecotoxicol. Environ. Saf. 2015, 113, 329-352. [CrossRef]

76. Mera, R.; Torres, E.; Abalde, J. Sulphate, more than a nutrient, protects the microalga Chlamydomonas moewusii from cadmium toxicity. Aquat. Toxicol. 2014, 148, 92-103. [CrossRef]

77. Adhiya, J.; Cai, X.; Sayre, R.T.; Traina, S.J. Binding of aqueous cadmium by the lyophilized biomass of Chlamydomonas reinhardtii. Colloid Surf. A-Physicochem. Eng. Asp. 2002, 210, 1-11. [CrossRef]

78. Tüzün, İ; Bayramoğlu, G.; Yalçin, E.; Başaran, G.; Çelik, G.; Arica, M.Y. Equilibrium and kinetic studies on biosorption of Hg(II), $\mathrm{Cd}(\mathrm{II})$ and $\mathrm{Pb}(\mathrm{II})$ ions onto microalgae Chlamydomonas reinhardtii. J. Environ. Manag. 2005, 77, 85-92. [CrossRef]

79. Maeda, S.; Sakaguchi, T. Introduction to Applied Phycology; Academic Publishing: Amsterdam, The Netherlands, 1990; pp. 109-136.

80. Rangsayatorn, N.; Upatham, E.S.; Kruatrachue, M.; Pokethitiyook, P.; Lanza, G.R. Phytoremediation potential of Spirulina (Arthrospira) platensis: Biosorption and toxicity studies of cadmium. Environ. Pollut. 2002, 119, 45-53. [CrossRef]

81. Solisio, C.; Lodi, A.; Soletto, D.; Converti, A. Cadmium biosorption on Spirulina platensis biomass. Bioresour. Technol. 2008, 99, 5933-5937. [CrossRef] 
82. Elleuch, J.; Ben Amor, F.; Chaaben, Z.; Frikha, F.; Michaud, P.; Fendri, I.; Abdelkafi, S. Zinc biosorption by Dunaliella sp. AL-1: Mechanism and effects on cell metabolism. Sci. Total Environ. 2021, 773, 145024. [CrossRef]

83. Salam, K.A. Towards sustainable development of microalgal biosorption for treating effluents containing heavy metals. Biofuel Res. J. 2019, 6, 948-961. [CrossRef] 